\title{
IMPACT OF ENDOPHYTIC LIPOPEPTIDES USE AGAINST SOME PLANT PATHOGENIC MICROORGANISMS
}

\author{
A. Mandour ${ }^{(1)}$, S. Fahim ${ }^{(2)}$, Walaa Hussein ${ }^{(3)}$, Wafaa Hanafy ${ }^{(2)}$ \\ and A. Elbeltagy ${ }^{(2)}$ \\ ${ }^{(1)}$ Ministry of Health, Shebin El kanater Hospitaly, Egypt. \\ (2) Agricultural Microbiology and Biotechnology, Botany Department, Faculty of \\ Agriculture, Menoufia University, Egypt. \\ (3) Genetics and Cytology Department, Genetic Engineering and Biotechnology Division, \\ National Research Centre (Affiliation ID : 60014618), Dokki, Egypt.
}

Received: Jan. 14, 2020

Accepted: Feb. 10,2020

ABSTRACT: Twelve dissimilar plant associated bacterial colonies were isolated from five different tomato seedlings, the Non Ribosomal Lipopeptides genes were detected by degenerated primers technique in the twelve tomato endophytic isolates, only the long rode bacilli endophytic strains were found to harbour the lipopeptides synthetases genes, these three strains were given laboratory names of (BMG100, BMG101 and BMG102) for further pursuit. Partial sequencing of 16s RNA gene and protein profile analysis for the three bacilli isolates showed that all isolates belonged to Bacillus subtilis. The lipopeptides production by HPLC analysis revealed that all the endophytic isolates from tomato stems had the ability to produce lipopeptides except the third isolate named B. subtilis BMG102 showed no production. different levels of volumetric oxygen transfer coefficient $\left(K_{L} a\right)$ were used as cursors for lipopeptides production. The maximum concentration of surfactin type was about 1431,529 and $437 \mathrm{mg} \cdot \mathrm{L}^{-1}$, the plipastitin (fengycin type) was $360198 \mathrm{mg}^{-L^{-1}}$ and zero while the Mycosubtilin (iturin type) was zero, 228 and $414 \mathrm{mg} \cdot \mathrm{L}^{-1}$ for the strains B. subtilis ATCC21332, BMG100 and BMG101, respectively. Surfactin production is visibly optimal at high oxygen transfer $\left(k_{L} a\right)$ and showed more than $0.07 \mathrm{~S}^{-1}$, while the optimum production of the fengycin and iturin could be observed at mild values of $\mathrm{O}_{2}$ transfer $\left(k_{L} a\right)$ which equal 0.01 and $0.015 \mathrm{~S}^{-1}$ respectively. The antibacterial - antifungal effects of the three B.subtilis extracts collected during lipopeptides productivity regimes showed inhibition activity against Pseudomonas syringae, Ralstonia solanacearum and Erwinia amylovora, as will as the antifungal activity against Aspergillus niger, Phanerochaete chrysosporium and Alternaria alternata. These results indicate potential use of B.subtilis strains as biocontrol agents, especially when considering commercial implementation. Studies regarding the lipopeptides applications, should also be considered as this will influence the efficacy of the lipopeptides against the target organisms.

Key words: Endophytic; Lipopeptides; Plant pathogens; Biocontrol agents.

\section{INTRODUCTION}

In Egypt, tomato (Solanum lycopersicum) are considered one of the most important vegetable crops and infected by numbers of different diseases. Studying the use of biological alternatives instead of chemical substances against plant diseases became necessary (Ongena et al., 2004). Beneficial microorganisms' endophytes can enhance plant resistance system to a wide range of pathogens, as bacteria, fungi, and viruses (Ongena and Jacques., 2008). Endophytes are considered groups of beneficial microorganisms which reside inside tissues of healthy and normal plant without any infectious 
symptoms (Robert et al., 2007). These endophytes can promote plant growth and plant disease management by producing metabolite substances. These substances are considered novel natural products for agricultural, medicinal, and industrial applications (Sturz and Kinpinski., 2004). Several studies have reported that some endophytes has the ability to excrete antimicrobial agents; surfactin consider one of these compounds, which is cyclic lipoheptapeptide biosurfactant produced by Bacillus subtilis various strains. It has shown inhibitory activities against some phytopathogenic bacteria, fungi, viruses, and mycoplasma (Nissen-Meyer and Nes., 1997). Endophytes have several benefits to plants (Sturz et al., 2000) such as: promoting growth (Kang et al., 2007) reducing disease severity (Coombs et al., 2004; Kloepper et al., 2004; Senthilkumar et al., 2007), inducing plant defence mechanisms (Bargabus et al., 2002; Mishra et al., 2006; Bakker et al., 2007), producing anti-herbivore products (Scott., 2001; Sullivan et al., 2007). Endophytes were investigated in the biological control of diseases on annual, perennial and biennial crops (Lodewyckx et al., 2002; Bargabus et al., 2002; Kloepper et al., 2004). Tomato bacterial wilts have some reports on their biological control (Li et al., 2003; Hu et al., 2006; Zhao et al., 2006; Almoneafy et al., 2012). Also, some reports have discussed the relationship between endophytes diversity and plant resistance (Araújo et al., 2002; Reiter et al., 2002). Moreover, the importance of tomato as a cultivated plant have risen the great role of the analysis of bacterial endophytes associated to these plants as a beneficial microorganisms. In the past, the control of post-harvest diseases has primarily been dependent on synthetic pesticides, however these substances have been shown to be harmful to both the environment as well as human health
(Pimentel, 2005). Due to the undesired effects associated with synthetic pesticides, stricter rules and regulations are being enforced with regards to maximize residue limits (Holzmann, 2010). In addition, the high costs associated with the discovery and development of new synthetic pesticides (Glare et al., 2012) have created a need for a viable alternative control method. Biocontrol is a promising alternative due to its biodegradability (Coutte et al., 2010), low toxicity (Nitschke and Costa, 2007), environmental compatibility (Ongena and Jacques, 2008), as well as the fact that government regulations favor their use (Fahim, 2017). Biological lipopeptides, more commonly known as biosurfactants, are one of the examples of biocontrol that have shown great potential in various fields of study, including pharmaceutical, cosmetic and remediation. Biological surfactants have been found to be extremely effective in controlling phytopathogens, but the majority of biocontrol strategies currently available employ the micro-organism itself directly as a countermeasure to the pest. This is demonstrated by the use of products like Serenade (Marrone, 2002) and Bioshield $^{\mathrm{TM}}$ (Jackson, 2007), where both products contain either living cells or endospores. Much of the research being carried out also includes the use of cells in the biocontrol agent (YanezMendizabal et al., 2012), making the current study very valuable, as it focused on the use of the lipopeptides, i.e. the products produced by the microorganisms. These are less sensitive to changes in $\mathrm{pH}$ or temperature compared to the organisms themselves, allowing for the production of a standardized product. An additional advantage to the use of lipopeptides instead of products containing living organisms is that there are fewer restrictions on importation and quarantine associated with these products. The main goal of this 
manuscript was to study lipopeptides production, specifically the antibacterial surfactin, antifungal lipopeptides fengycin and iturin. Parameters associated with lipopeptides production were quantified and the production of the antifungal lipopeptides was optimized and the efficacy of the lipopeptides was tested against specific phytopathogens. Important factors in the study included the choice of organism to be used for lipopeptides production, growth medium composition as well as the process conditions under which production would be optimal. The aim of this work is to indicate the potential use of $B$. subtilis strains as biocontrol agents, especially when considering commercial implementation. Studies regarding the lipopeptides applications, should also be considered as this will influence the efficacy of the lipopeptides against the target organisms.

\section{MATERIAL AND METHODES}

\section{Microbial and plant strains}

Various strains of Bacillus genus were used in this work, wild type Bacillus subtilis ATCC 21332 was gathered from the culture collections of Microbial Biotechnology laboratory, Faculty of Agricultural, Menuofia University, Egypt. This strain was used as a model in order to estimate the conditions of lipopeptides production as surfactin and fengycin coproducer in aerobic condition (Fahim et al., 2012). The Bacillus strains named BMG100, BMG101 and BMG102 were isolated from tomato plant microbiome. Cultivar of super marmand tomato seedlings (Lycopersicon esculentum) were collected from the agriculture farm of Ain-Shams University, Egypt. The pathogenic strains which were used as a models in order to estimate the conditions of antimicrobial tests were collected from the plant pathology laboratory, Botany department, Faculty of
Agricultural, Menuofia University, Egypt. The bacterial strains concluded Pseudomonas syringae, Ralstonia solanacearum and Erwinia amylovora. While, the fugal strains concluded Aspergillus niger, Phanerochaete chrysosporium and Alternaria alternata. This strains were recently proved to be a top plant pathogenic micro-organisms which affected on tissue culture and post harvest technologies.

\section{Bacterial isolation and cultivation conditions}

The strains used in this work were grown aerobically in Luria-Bertani (LB) medium at $30^{\circ} \mathrm{C}$. While, for lipopeptides production, Landy modified Medium was used under $30^{\circ} \mathrm{C}$ and $\mathrm{pH} 7.0$ using three oxygen transfer selective production regimes according to (Fahim, and Hussein 2016).

Regime 1: (flask size of $50 \mathrm{~mL}$ with proportional volume of $0.05 \mathrm{~mL} \cdot \mathrm{mL}^{-1}$ flask) and shaking frequency of 250 r.p.m, in these conditions, $k_{L} a$ was higher than $0.06 \mathrm{~s}^{-1}$ and the ratio between the surfactins and others lipopeptides concentrations ( $\boldsymbol{R}_{\text {surf/lipo }}$ ) was reached 50.

Regime 2: (flask size of $50 \mathrm{~mL}$ with a proportional volume of $0.2 \mathrm{~mL} \cdot \mathrm{mL}^{-1}$ ) flask) and shaking frequency of 150 r.p.m., these conditions $k_{L} a$ was less than $0.003 \mathrm{~s}^{-1},\left(R_{\text {surf/lipo }}\right)$ was reached about 5 .

Regime 3: (flask size of $1000 \mathrm{~mL}$ with a proportional volume of $0.4 \mathrm{~mL} \cdot \mathrm{mL}^{-1}$ flask) and shaking frequency of 250 r.p.m, these conditions $k_{L} a$ was about $0.015 \mathrm{~s}^{-1}$ and $\left(R_{\text {surf/ipo }}\right)$ was reached about 0.5 . The lipopeptides production obtained in different production regimes were measured with standard deviation percentage between 3.34 and $9.96 \%$ for surfactin and kurstakin values and between 2.03 and $59.55 \%$ for iturin and fengycin values. This condition was tested in each Bacillus strain, the 
cultures were performed during $48 \mathrm{~h}$ of fermentation (stationary phase) at $30^{\circ} \mathrm{C}$ in modified Landy MOPS medium with glutamic acid, the obtained results are means of three replicates with its standard deviations. For endophytic micro biome bacteria isolation process, the tomato stems surfaces were sterilized according to (Maurice et al., 2009; Wen et al., 2011). The attached dust and soil were removed from samples by washing with tap water, then $70 \% \mathrm{C}_{2} \mathrm{H}_{5} \mathrm{OH}$ for $1 \mathrm{~m}$ and $5 \% \mathrm{NaOCl}$ for $5 \mathrm{~m}$ were used to sterilize samples tissues. After that, samples were rinsed with sterilized distilled water three times, outer tissues were removed, and then were cut into fragments of $0.5 \mathrm{~cm}$ long. The plant fragments were sterilized one more time with $70 \% \mathrm{C}_{2} \mathrm{H}_{5} \mathrm{OH}$ for $10 \mathrm{~s}$ and rinsed by sterilized water five times, then fragments were incubated on YPDA medium ( $\mathrm{pH} 6.7$ ) at $30^{\circ} \mathrm{C}$ until the appearance of colonies, which were purified and re-cultured on YPDA agar slants. At the same time, a negative control was performed without surface sterilization and a positive control of $\mathbf{1 0 0}$ $\mu \mathrm{l}$ of the last rinsed water were microbiological cheeked.

\section{Equations and analytical methods}

Microbial growth determination: The cell density was measured by various methods; (a direct method) by measuring the cell dry weight; (an indirect method) by measuring the density absorbance measurements. Cell dry weight (CDW): Shaken flasks during the stationery phase cultivation were incubated for 48 $h$, the serial dilution were applied. samples of $10 \mathrm{~mL}$ were collected from each dilution after filtration the bacterial cells pellet was discarded from the supernatant. A vacuum filtration (Buchner, Millipore ${ }^{\circledR} 0.2 \mu \mathrm{m}, \mathrm{GR}$ ) were used for filtration, microbial filter disks were oven dried at $60^{\circ} \mathrm{C}$ for $24 \mathrm{~h}$. After drying it were cooled in a glass desiccator, the filters were weighed to calculate the difference between the weight after and before filtration which represents as CDW. The wave length of $600 \mathrm{~nm}$ (visible light) were used for optical density measurements, this wave length were found to have the least amount of the growth medium. A free culture medium was used as standard blank for the cell absorbance measurements, the absorbance of the culture medium with growth was then measured at $600 \mathrm{~nm}$. To avoid the false spectrophotometer sensitivity, samples cases of optical densities with absorbance exceeding 0.81 were decimal diluted to ensure that it were remained within the linear region.

$\left(k_{L} a\right)$ and $\left(P_{V L}\right)$ quantifications: To achieve the volumetric oxygen transfer coefficient $k_{L} a$ in Erlenmeyer flasks, the investigated empirical equation was applied: $K_{L} a=6.67 \times 10^{-6} N^{1.16} V L^{-0.83} d^{1.92}$ $d_{0}^{0.38}$ where $(M)$ is the agitation rate by $\left(m n^{-1}\right),\left(V_{L}\right)$ the proportional volume $(m L)$, $\left(d_{0}\right)$ the shaker axe diameter $(\mathrm{cm})$ and $(d)$ the standard inner diameter of Erlenmeyer flask $(\mathrm{cm})$. This latest equation was previously suggested by (Fahim and Hussein., 2016) for hydrophilic Erlenmeyer flasks, the axe shaker diameters of $5 \mathrm{~cm}$, the proportional volumes of 0.05 to 0.4 $m L . m L^{-1}$, agitation rate within 150 to300 $\mathrm{min}^{-1}$. Also, the power dissipation $(P)$ was calculated according to the correlation proposed by (Fahim and Hussein., 2016) using the Reynolds number $(R e)$ and modified Newton number $(\mathrm{Ne}): \quad P=\mathrm{Ne}$ $N^{3} \rho d^{4} V_{L}{ }^{0.33}$; whereas $\mathrm{Ne}=70 \mathrm{Re}^{-1}+$ $25 R e^{-0.6}+1.5 R e^{-0.2}$ While, the Reynolds number was calculated as $(R e)=N d^{2} \rho / \mu$ $; \ldots \rho\left(\mathrm{kg}^{-3} \mathrm{~m}^{-3}\right)$ was water density and $\mu$ (Pa.s) the water dynamic viscosity at $30^{\circ} \mathrm{C}$. the ratio between oxygen transfer coefficient $k_{L} a$ and the power dissipation $(P)$ was calculated for each kind of Erlenmeyer flask, for various 
proportional volumes $(R v$ from 0.05 to 0.4 $\left.m L . m L^{-1}\right)$ and shaking frequencies from 150 to $350\left(\mathrm{~min}^{-1}\right)$ according to thee procedures developed by (Fahim, 2017).

\section{Molecular characterization tools for bacterial isolates}

Total proteins analyses and DNA isolation: The protocol of DNA Genomic isolation and purification kit was applied using the wizard of (Promega Co., Appl Microbiol Biotechnol Madison, USA). The concentration of DNA was measured by $\mathrm{A}_{260}$ direct method (1 ABS = $1 \mathrm{mg} \cdot \mathrm{mr}^{1}$ ), the absorption at $260 \mathrm{~nm}$ was measured using NanoDrop UV-Vis spectrophotometer (Thermo Fisher Scientific ${ }^{\mathrm{TM}}$ ). The purified DNA was directly used for PCR amplification or stored at $-20{ }^{\circ} \mathrm{C}$. For total protein analysis, Protein precipitation was carried out with salting technique by adding ammonium sulphate slowly to the cell-free culture (at $75 \%$ saturation), the frequently shaking using magnetic stirrer was done to precipitate the protein, the precipitate was collected by centrifugation at $10,000 \times g$ for $20 \mathrm{~min}$ and then dissolved in $50 \mathrm{mmol}$ phosphate buffer (pH 8.0), dialyzed and stored at $20^{\circ} \mathrm{C}$ (Switzer et al., 1979). For molecular weight determination, the sodium dodecyl sulphate polyacrylamide gel electrophoresis (SDS-PAGE) profiles for extra-cellular degrading enzymes were preformed, the gel made of (10\%) polyacrylamide and $5 \%$ stacking gels. After electrophoresis run, the gels were stained with Coomassie brilliant Blue R250 staining method and overnight destained by $45 \%$ methanol and $10 \%$ acetic acid (Pant et al., 2015). The gel was stained for $12 \mathrm{hr}$ in $0.1 \%$ coomassie brilliant blur and distained until bands were clearly observed. Gel bands were scanned and analysed using (Gel Doc Bio-Rad system, USA).
Endophytic bacteria identification by 16S rDNA

The three long rod bacilli isolates were grown on YPDA medium, their total bacterial DNA were previously extracted by genomic DNA kits. The technique of bacterial 16S rDNA universal primers were used as described by (Teng et al., 2006) 28 F: 5'AGAGTTTGATCCTGGCTCAG-3' also 1493 R: 5'-TACCTTGTTACGACTT-3'.

PCR conditions started with initial denaturation step at $95^{\circ} \mathrm{C}$ for two minutes and 35 cycles of $45 \mathrm{sec}$ at $95^{\circ} \mathrm{C}$ and then the annealing step at $50^{\circ} \mathrm{C}$ for $45 \mathrm{~s} \mathrm{sec}$ and followed by elongation step at $73^{\circ} \mathrm{C}$ for $1.5 \mathrm{~min}$ and the final extension at $73^{\circ} \mathrm{C}$ for $10 \mathrm{~min}$.

Plant associated bacterial 16S rDNA and PCR amplification. The obtained PCR fragments were amplified with universal bacterial 16S rDNA primers Table (1), the PCR products were extracted and purified using ZymocleanTm Gel DNA recovery kit (Epigenetics Company). The purified PCR products were ligate by using pGEMR - TEasy vector and then, the transformation into E. coli DH5a was completed. The transformants $\mathrm{E}$. coli DH5a colonies were grown on LB plates supplemented with $55 \mathrm{mg} \cdot \mathrm{L}-1$ of ampicillin antibiotic. White colonies were selected for extracting their plasmid DNA by using plasmid miniPREP Kit (GeneDireX). Plasmids were double digested with EcoRI to verify the insertion of interested fragments then, amplified fragments were migrated on $1.2 \%$ agarose gel electrophoresis. Cloned products were sequenced and aligned with the databases available in GenBank (BLAST) online software of NCBI.

Detection of lipopeptides
production genes. 
The sequence published for Bacillus subtilis 168 lipopeptides operon were used to primers design as accession number of AL009126. Known DNA sequences of Bacillus subtilis which are involved in lipopeptides synthesis operons were compared with online Needle software (Needleman and Wunsch., 1970). Lipopeptides genes detection by degenerated primers: degenerated primers for surfactin, fengycin, iturin, and kurstakin families were applied to investigate the gene absence or presence of NRPS, the PCR conditions were performed as described (Tapi et al., 2006; Hussein and Fahim., 2017).

\section{Lipopeptides extraction and purification and detection.}

Microbial fermentation was lanced in Landy modified medium for $48 \mathrm{~h}$ (stationary phase), the bacterial cells were discarded from fermented media by centrifugation with 14.000 r.p.m for 20 min at $5^{\circ} \mathrm{C}$ according to (Fahim, 2017). For lipopeptides extraction, $0.5 \mathrm{ml}$ supernatants samples were passing through clean $\mathrm{C}_{18}$ cartridges (protocol of Alltech, Fr). Lipopeptides were washed with $3 \mathrm{ml}$ of methanol grade; Sigma alderch, India). The elution was cold dried at $5{ }^{\circ} \mathrm{C}$, the residues in glass tube bottom were re-dissolved in $200 \mu \mathrm{l}$ of methanol grade. And then samples were injected on high-performance liquid chromatography (HPLC) using a $\mathrm{C}_{18}$ column $(5.1 \mu \mathrm{m} ; 255$ by $4.5 \mathrm{~mm}$; VYDAC 218 TP, Hesperia, GE). The concentrations of lipopeptides families were determined by the spectrum of (HPLC) reverse phase, the produced lipopeptides were extracted after microbial batch fermentation. kurstakin produced strains, cells were collected and sonicated for $1 \mathrm{~min}$ at low temperature at 6 Watt (Ultrasonic processor, Cole-Parmer Instruments, Illinois, USA). The total yield was gathered before analysis by (HPLC) using a $\mathrm{C}_{18}$ column $(5.1 \mu \mathrm{m} ; 255$ by $4.5 \mathrm{~mm}$; VYDAC 218 TP, Hesperia, GE). The mobile phases were iso-critical acetonitrile-water-trifluoroacetic acid solvent system (80:20:0.5, 55:45: 0.5 , 45:55:0.5 and 40:60:0.5 [vol $/ \mathrm{vol} / \mathrm{vol}]$ for surfactin; kurstakin; fengycins or plipastatins; iturins families, respectively). (20 $\mu$ ) of collected samples were injected through (HPLC) $\mathrm{C}_{18}$ column at a flow rate of $0.5 \mathrm{ml} \cdot \mathrm{min}^{-1}$. Surfactin (Sigma), kurstakin, fengycins or plipastatins, iturins were purchased with purity of $98 \%$ as standards. The spectrum of second derivatives of UV-visible and the retention time of each peak was used to identify the lipopeptides molecules (Waters integrated PDA 996 diode array detector; Millenniums Software) according to (Fahim, 2017).

Table (1). Degenerated primers for detection of lipopeptide biosynthesis genes.

\begin{tabular}{|c|c|c|c|c|}
\hline $\begin{array}{l}\text { Primers } \\
\text { Names }\end{array}$ & Sequence of primers & $\begin{array}{l}\text { Expected } \\
\text { Fragment } \\
\text { size (bp) }\end{array}$ & $\begin{array}{l}\text { (NRLPs) } \\
\text { identified }\end{array}$ & References \\
\hline Ap1- F & AGMCAGCKSGCMASATCMCC & \multirow{2}{*}{$893 / 929$} & \multirow{2}{*}{ Plipastatin } & \multirow{5}{*}{$\begin{array}{c}\text { Tapi } \\
\text { et al., } 2010\end{array}$} \\
\hline Tp1- R & GCKATWWTGAARRCCGGCGG & & & \\
\hline Am1-F & CAKCARGTSAAAATYCGMGG & \multirow{2}{*}{$416 / 419$} & \multirow{2}{*}{ Mycosubtilins } & \\
\hline Tm1-R & CCDASATCAAARAADTTATC & & & \\
\hline As1-F & CGCGGMTACCGVATYGAGC & $422 / 425 / 431$ & Surfactins & \\
\hline
\end{tabular}


Impact of endophytic lipopeptides use against some plant pathogenic

\begin{tabular}{|c|c|c|c|c|}
\hline Ts2-R & ATBCCTTTBTWDGAATGTCCGCC & & & \\
\hline Aks-F & TCHACWGGRAATCCAAAGGG & ND & Kurstakins & $\begin{array}{c}\text { Abderrahmani } \\
\text { et al., } 2011\end{array}$ \\
\hline Tks-R & CCACCDKTCAAAKAARKWATC & & &
\end{tabular}

\section{Lipopeptides antagonistic and antimicrobial testing.}

Primary antimicrobial testing was performed using Kirby-Bauer technique according to the disk diffusion protocol described by the clinical laboratory standards institute (CLSI) guidelines using following standard lipopeptides discs: surfactin, iturin and fengycin with doses of 50,150 and $350 \mu \mathrm{g}$ for each lipopeptides susceptibility disk. The microbial isolates were inoculated onto a Muller-Hinton agar (Oxoid) plate and lipopeptides discs were added to the surface of the solid medium. The prepare disk diffusions plates were incubated at $30^{\circ} \mathrm{C}$ for $20 \mathrm{~h}$. After microbial growth, the inhibition zones diameters were measured (by millimetres) to assess susceptibility or non-susceptibility according to the interpretation criteria for each fungal and bacterial strains established by the (CLSI) guidelines prepared by (Cockerill ., 2012).

Antibacterial activity test was determined by using Mueller-Hinton agar plates and carried out according to the protocol described by (CLSI) guidelines as follows: The overnight bacterial cultures grown on Mueller-Hinton broth (Oxoid) were adjusted to the density of 0.5 standard McFarland turbidity unit. The inoculation of the tested microorganisms were placed streaky on to Mueller-Hinton medium (Oxoid) using a cotton swab. Whatman sterile discs with $6 \mathrm{~mm}$ diameter (Whatman- $\mathrm{N}^{\circ}:(1)$, England) impregnated with $(20 \mu \mathrm{l} /$ disc) from purified produced lipopeptides mixtures (surfactins, iturins and fengycins), were added on the used solid culture medium, distilled water was used as negative control. After microbial growth, the inhibition zones diameters were measured (by millimetres) to assess susceptibility or non-susceptibility according to the interpretation criteria for each fungal and bacterial strains established by the (CLSI) guidelines. The experiments were carried out in three replicate and the inhibition zones diameters empirical means were noted with its standard divisions. While, the minimal inhibitory concentrations (MICs) $\mu \mathrm{g} \cdot \mathrm{mL}^{-1}$ were calculated as the lowest lipopeptides concentrations of the mixtures that completely inhibited the microbial growth of each model fungal or bacterial strain. The lipopeptides cultures media (supernatant) were purified and injected within the culture medium (Mueller-Hinton broth with decimal dilutions to investigate the final concentrations from zero to $350 \mu \mathrm{g} \cdot \mathrm{mL}^{-1}$, the examined tubes were inoculated by 100 colony (cfu.mL ${ }^{-1}$ ) and incubated at $30^{\circ} \mathrm{C}$ for $20 \mathrm{~h}$ (Cockerill ., 2012). The controlling of microbial growth consisting comparing with growth culture and clear media (positive or negative control) to achieve the dilutions which were used in the applications treatments. In addition, the minimum bacterial concentration (MBCs) and (MFCs) were applied to detect the test model microbial cells which were killed or only inhibit their growth. The poured plates of Mueller-Hinton solid medium were autoclaved at $110^{\circ} \mathrm{C}$ for 30 minutes. The recorded MBCs or MFCs decimal dilutions were sub-cultured onto other prepared culture medium, the plates were incubated at $30^{\circ} \mathrm{C}$ for $20 \mathrm{~h}$, after microbial growth, the lowest lipopeptides concentrations without any microbial growth were noted as the MBCs or 
A. Mandour, et al.,

(MFCs) according to CLSI guidelines (Cockerill ., 2012).

\section{RESULTS AND DISCUSSION}

1. Isolation and identification of lipopeptides producers

\section{1-1. Endophytic isolation from tomato plants}

Twelve dissimilar plant associated bacterial colonies were isolated aerobically on YPDA medium from five different tomato seedlings of super marmand cultivars. Three bacterial isolates were belonged morphologically to spore forming long rode bacilli, as showed a positive result with Gram and spore staining. The other endophytic bacterial isolates, seven of them were belonged to short bacilli and two isolates were small cocci. These isolates revealed a negative result with gram and spore staining. Several reports have discussed the relationship between endophytes diversity and plant resistance (Araujo et al., 2002). Moreover, the tomato importance as a cultivated plant have risen the great role of the analysis of bacterial endophytes associated to these plants as a beneficial microorganisms (Reiter et al., 2002). Also, a lot of studies have reported that some endophytes have the ability to excrete antimicrobial agents; surfactin consider one of these compounds, which is cyclic lipoheptapeptides biosurfactant produced by Bacillus various strains, it has shown inhibitory activities against some phytopathogenic bacteria, fungi, viruses, and mycoplasma (Phae et al., 1990).

\section{1-2. Non ribosomal Lipopeptides genes detection}

The Non Ribosomal Lipopeptides genes were detected by degenerated primers technique in the twelve tomato endophytic isolates, four genes were amplified; Srf (surfactin-surfactin), Pps (plipastatin-fengycin), Myc (mycosubtiliniturin) and Krs (kurstakin-kurstakin) by degenerated primers, respectively. The endophytic short rode bacilli and coccii forms strains had no fragments amplified with the four degenerated primers. While, only the long rode bacilli endophytic strains were found to harbour the lipopeptides synthetases genes, these three strains were given laboratory names of (BMG100, BMG101 and BMG102) for further pursuit. The observed fragment length from used degenerated primers for the standard lipopeptides producer, Bacillus subtilis ATCC 21332 strain, and tomato associated bacilli isolates were mentioned in Table (2).

Bacillus subtilis ATCC 21332 strain was given two fragments sizes of 431 and $893 \mathrm{bp}$ length for amplified surfactins and fengycins primers, respectively. While, the endophytic strain BMG100 was given three fragments sizes of 425,893 and 419 bp length for amplified surfactins, fengycins and iturins primers, respectively. The endophytic strain BMG101 was given two fragments sizes of 431 and 416 bp length for amplified surfactins and iturins degenerated primers respectively. Also, the endophytic strain BMG102 was given two fragments sizes of 422 and 929 bp length for amplified surfactins and fengycins degenerated primers respectively. As mentioned above, no fragments were amplified with kurstakin degenerated primer for all examined strains. The use of Pps primers could amplify fragment length about 893 bp from Bacilli sp. BMG100 belongs to plipastatin synthetases genes, which was confirmed before in Bacillus subtilis ATCC 21332 strain by (Hussein and Fahim., 2017). In general, degenerated primers approach led to achievement of NRPs genes presence in tomato associated bacilli 
isolates, this was confirmed before by (Tapi et al., 2010) who reported that the use of degenerated primers are helpful in screening the various non-ribosomal synthesis genes harbor by Bacillus spp. which supported to detect a new nonribosomal synthesis molecules and it

Table (2): NRPs fragment detected by degenerated primers for lipopeptides producing strains.

\begin{tabular}{|c|c|c|c|c|}
\hline \multirow{2}{*}{$\begin{array}{c}\text { Sequence } \\
\text { origins }\end{array}$} & \multicolumn{4}{|c|}{ Degenerated primers sizes } \\
\cline { 2 - 5 } & $\begin{array}{c}\text { Srf } \\
\text { primer }\end{array}$ & $\begin{array}{c}\text { Pps } \\
\text { primer }\end{array}$ & $\begin{array}{c}\text { Myc } \\
\text { primer }\end{array}$ & $\begin{array}{c}\text { Krs } \\
\text { primer }\end{array}$ \\
\hline Bacillus subtilis 21332 & 431 & 893 & ND & ND \\
\hline Bacilli sp. BMG100 & 425 & 893 & 419 & ND \\
\hline Bacilli sp. BMG101 & 431 & ND & 416 & ND \\
\hline Bacilli sp. BMG102 & 422 & 929 & ND & ND \\
\hline
\end{tabular}

ND: Not detected

\section{1-3. Identification of endophytic bacteria by $16 \mathrm{~S}$ rRNA gene}

The amplified fragment of 16S rDNA gene of the three endophytic Bacilli isolates were $600 \mathrm{bp}$ in length as shown in Fig (1). While, their sequences were compared and aligned with Blast databases which were found to belong to Bacillus sp.

The sequence of 16S rRNA gene of BMG 100 showed similarity to the Bacillus subtilis strain MZS1 sequence (accession $\mathrm{N}^{\circ}$ : KJ882376.1) by (85\%) Also, it has similarity to Bacillus amyloliquefaciens strains SRM sequence (accession $\mathrm{N}^{\circ}$ : KY401501.1) by $84 \%$. Also, the sequence of $16 \mathrm{~S}$ rRNA gene of the isolated BMG101 have similarity to Bacillus subtilis strain MZS1(accession $\mathrm{N}^{\circ}$ : KJ882376.1) sequence by $(85 \%)$. While was similar to Bacillus pumilus strain SR110 (accession $N^{\circ}:$ KY111721.1) sequence by $(84 \%)$. The sequence of third Bacilli BMG102 strain, was similar by $(81 \%)$ with those of Bacillus subtilis facilitate the study and genetic potential knowledge of lipopeptides molecules biosynthesis. 
1-5. Total proteins SDS-PAGE profile analysis

SDS-PAGE for total extracted proteins from the endophytic strains Bacilli
BMG100 BMG101 and BMG102 showed 28 polymorphic bands. Both Bacilli BMG100 and BMG101 were showed ten bands patterns, while Bacilli BMG102 showed pattern of 12 bands, Fig (3).

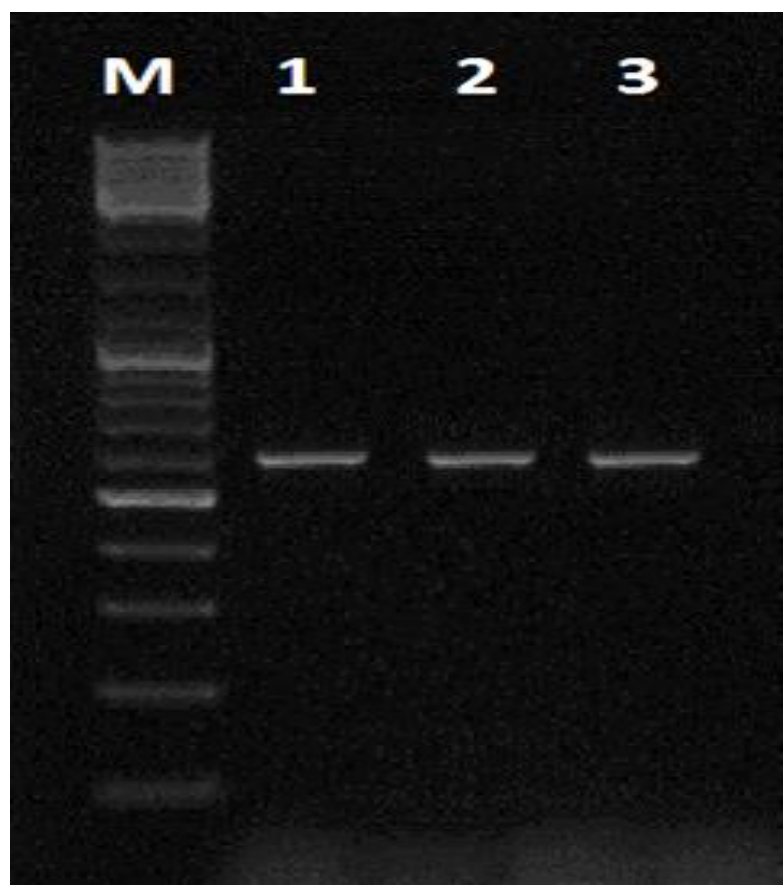

Figure (1). PCR amplification of 16S rDNA genes of the three endophytic isolates. 


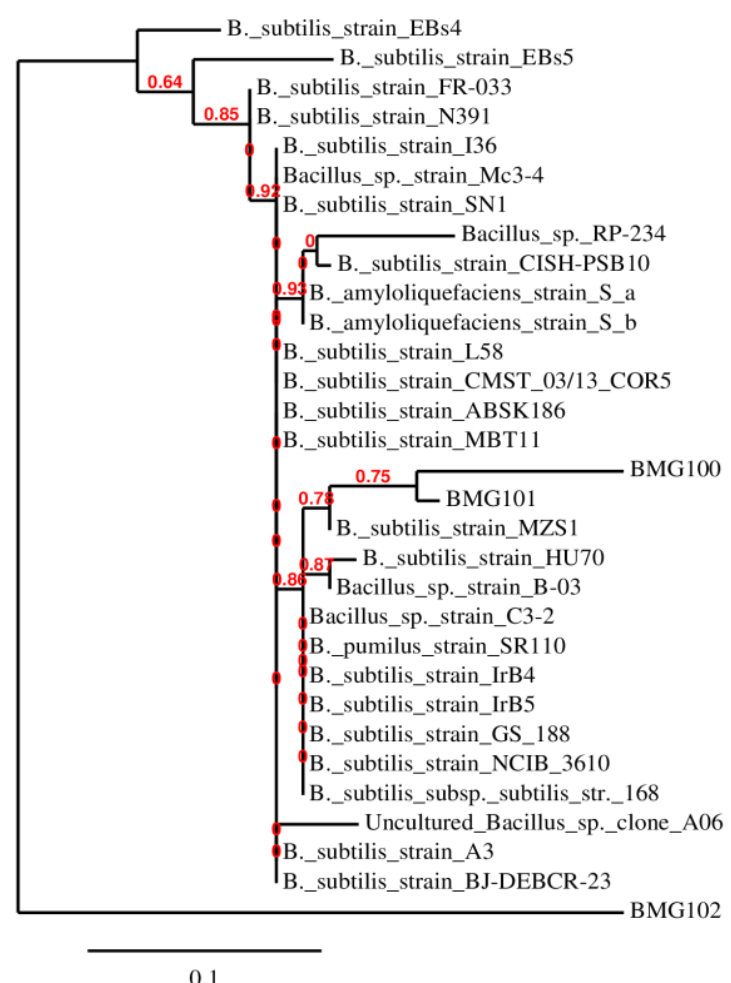

0.1

Figure (2): Phylogenetic tree based on alignment of 16S rRNA gene sequence of tomato associated Bacilli strains with other Bacillus strains.

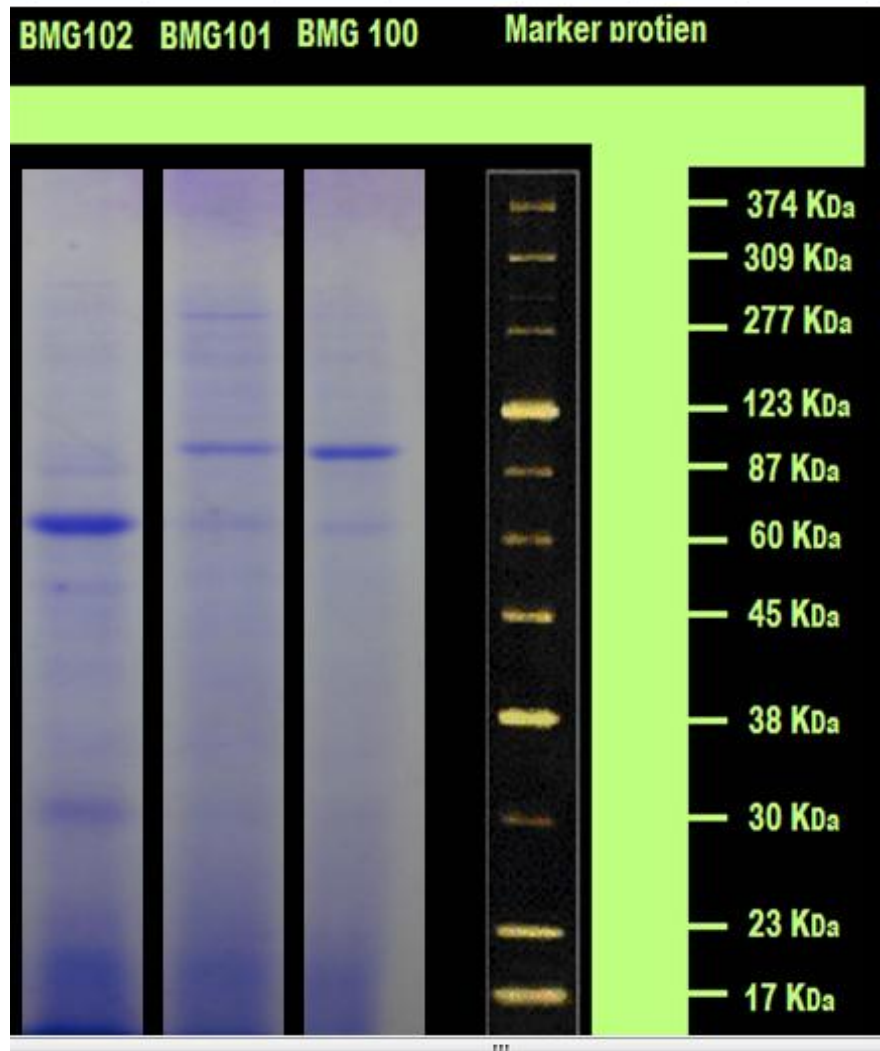


A. Mandour, et al.,

Figure (3): SDS-PAGE total proteins profiles extracted from the isolated Bacilli endophytic strains

On the other side, genetic similarity coefficient grouped the three strains into one main cluster of Bacilli BMG102 that include both Bacilli BMG100 and BMG101. Genetic distance ranged from 0.2 for Bacilli BMG102 to 0.36 for both Bacilli BMG100 and BMG101 as mentioned in Fig (4).

\section{Production of Non Ribosomal Lipopeptides}

2-1. Primarily lipopeptides production investigation

In this study lipopeptides production by $B$. subtilis ATCC 21332 and the isolated endophytic $B$. subtilis BMG100, BMG101and BMG102 which isolated in laboratory of Microbial Biotechnology laboratory, Faculty of Agricultural, Menuofia University, Egypt were investigated. Previous study showed that, $B$. subtilis 21332 strain was thought to be lipopeptides co-producer for both surfactin and plipastatin (Gancel et al., 2009). While, the primarily lipopeptides production experimentations under investigation condition showed different type of lipopeptides production by the endophytic strains. The evolution of lipopeptides production of each endophytic strains was carried out in modified Landy medium at $\mathrm{pH} 7.2$ and
$30{ }^{\circ} \mathrm{C}$, the results details presented in Fig (5).

The production quantification of lipopeptides by HPLC revealed the ability of first isolate strain B. subtilis BMG100 to produce three types of lipopeptides, (surfactin, plipastatin and Mycosubtilin) which belonging to (surfactin, fengycin and iturin families) by 293, 105 and 178 $\mathrm{mg} \cdot \mathrm{L}^{-1}$, respectively. The second isolate strain B. subtilis BMG101 was found to co-produce surfactin and mycosubtilin (surfactin and iturin families) by 385 and $236 \mathrm{mg} \cdot \mathrm{L}^{-1}$, respectively. Although, the third isolate strain $B$. subtilis BMG102 showed no lipopeptides production although it showed presence of lipopeptides production genes. These results proved that, all the endophytic isolates from tomato seedling had the ability to produce lipopeptides except the third isolate named $B$. subtilis BMG102 which showed no lipopeptides production by HPLC, it was also found that endophytic isolates are coproducers of three families of lipopeptides; surfactin, fengycin and iturin which known as inducers of systemic resistance system in plant (Hussein and Fahim., 2016). 
UPGMA

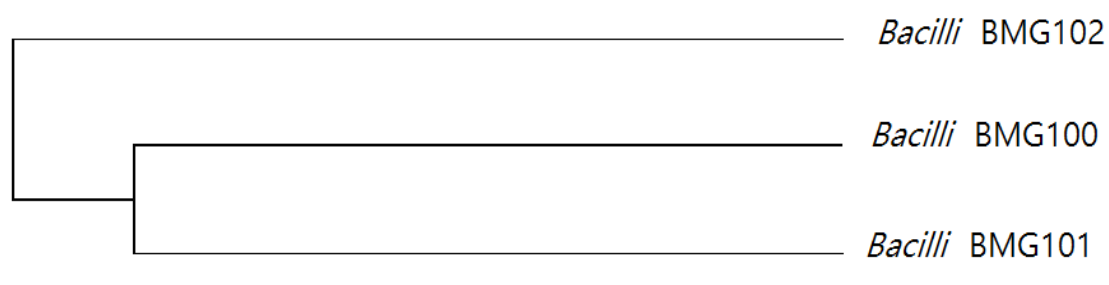
0.74
0.2
0.36
0.52
0.68
$0.84 \quad 1$
Nei $\&$ Li's Coefficient

Figure (4): SDS-PAGE based cluster formation of the Bacilli endophytic strains

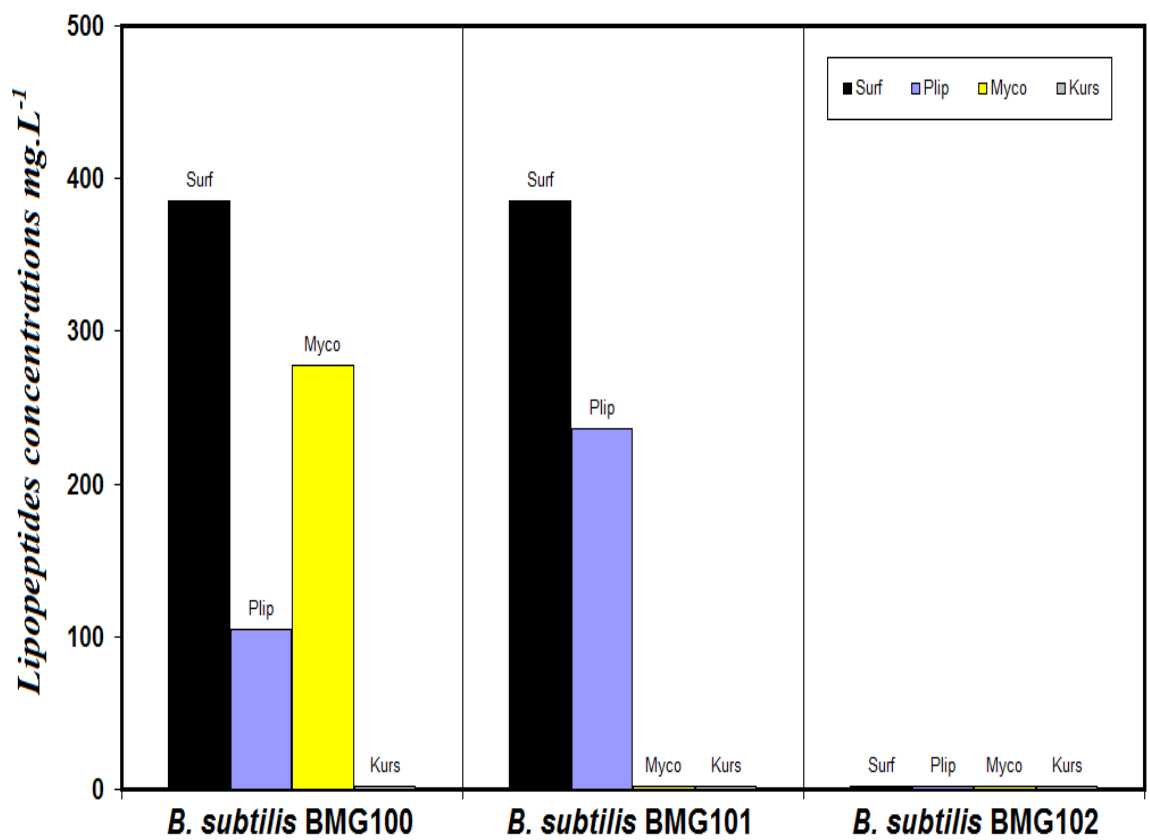

Figure (5): The evolution lipopeptides production of tomato endophytic strains

\section{2-2. Kinetic of NRPs lipopeptides productivity}

The kinetic study of the evolution of biomass and lipopeptides production of each endophytic strains was determined during $96 \mathrm{~h}$ of fermentation, the results of various experiments indicated that the fengycins or iturins had complete contrary behaviour with oxygen transfer $\left(K_{L} a\right)$ function. While, there was a positive correlation between surfactins productivity and increasing, $K_{L} a$, this phenomena behind the increase of surfactin and decrease of fengycin or iturin concentrations levels. The maximum productivity of lipopeptides families were noted during various period of fermentation depending on the lipopeptide type and cultivation condition, thus leading to different lipopeptides and its family type 
production at various $K_{L} a$ levels. These levels of $K_{L} a$ were used as cursors for surfactins, fengycins and iturins production from the various $B$. subtilis strains. At the many studies conditions, Bacillus amyloliquefaciens strains produced three families of lipopeptides; surfactin, fengycin and iturin (mycosubtilin type) according to Fahim, (2017). The standard $B$. subtilis ATCC21332 and the endophytic $B$. subtilis BMG101 strain produced two families of lipopeptides surfactin and fengycin (plipastatin type). While, strains of $B$. subtilis BMG100 produced the three lipopeptides families surfactin with the two types (plipastitin and mycosubtilin), the strain $B$. subtilis BMG102 showed no detectable for lipopeptides production as summarized in Table (3).

In all cases, $B$. subtilis strains was more surfactins productivity than iturin or fengycin types. Adjusting the shaking frequencies and the Erlenmeyer flask sizes led to adjust $K_{L} a$ levels which controlled the lipopeptide concentration and the selectivity of family type, the most suitable conditions for increasing surfactins types production was flask size minimization and increasing shaking frequency, while the fengycin and iturins types were maximized at low shaking frequency and biggest flask size, The obtained maximum concentration of surfactin type using $50 \mathrm{~mL}$ flask at $R v=$ $0.05 \mathrm{~mL} . \mathrm{mL}^{-1}$ and shaking frequency of $250 \mathrm{~min}^{-1}$ was about 1431,529 and 437 $\mathrm{mg} \cdot \mathrm{L}^{-1}$ for the strains $B$. subtilis ATCC21332, BMG100 and BMG101, respectively. A different behaviour was observed for fengycin type (plipastatin) and iturin (mycosubtilin), the concentrations levels weren't the same with adjusted relative filling volume and shaking frequency for the various flasks size. The smaller ones $(50 \mathrm{~mL})$ enhanced the maximum plipastitin production with
$R v$ increasing from 0.05 to $0.4 \mathrm{~mL}^{\mathrm{mL}} \mathrm{L}^{-1}$ which was 360 and $198 \mathrm{mg} \cdot \mathrm{L}^{-1}$ for $B$. subtilis ATCC21332, BMG100 and BMG101, respectively. The same thing was happened with mycosubtilin production with $R v$ increasing from 0.05 to $0.4 \mathrm{~mL} . \mathrm{mL}^{-1}$ which was 228 and 414 $m g . L^{-1}$ for $B$. subtilis $B M G 100$ and BMG101, respectively. The shaking frequencies effect on fengycin and iturin production is very complicated since the increasing of oxygen supply of the culture media which is favoured for iturins and fengycins production could be observed by combined the agitation, filling volume and the size of flask. Many authors reported that, Bacillus subtilis is known to produce lipopeptides aerobically and able to grow under microaerobic conditions, the $K_{L} a$ values can thus had a strong effect of Bacillus metabolism which have a complex regulatory system according to (Fahim et al., 2012). Other investigation found that the production of lipopeptides by $B$. subtilis ATCC 6633 was determined based on the oxygenation levels (Chtioui et al., 2010). 


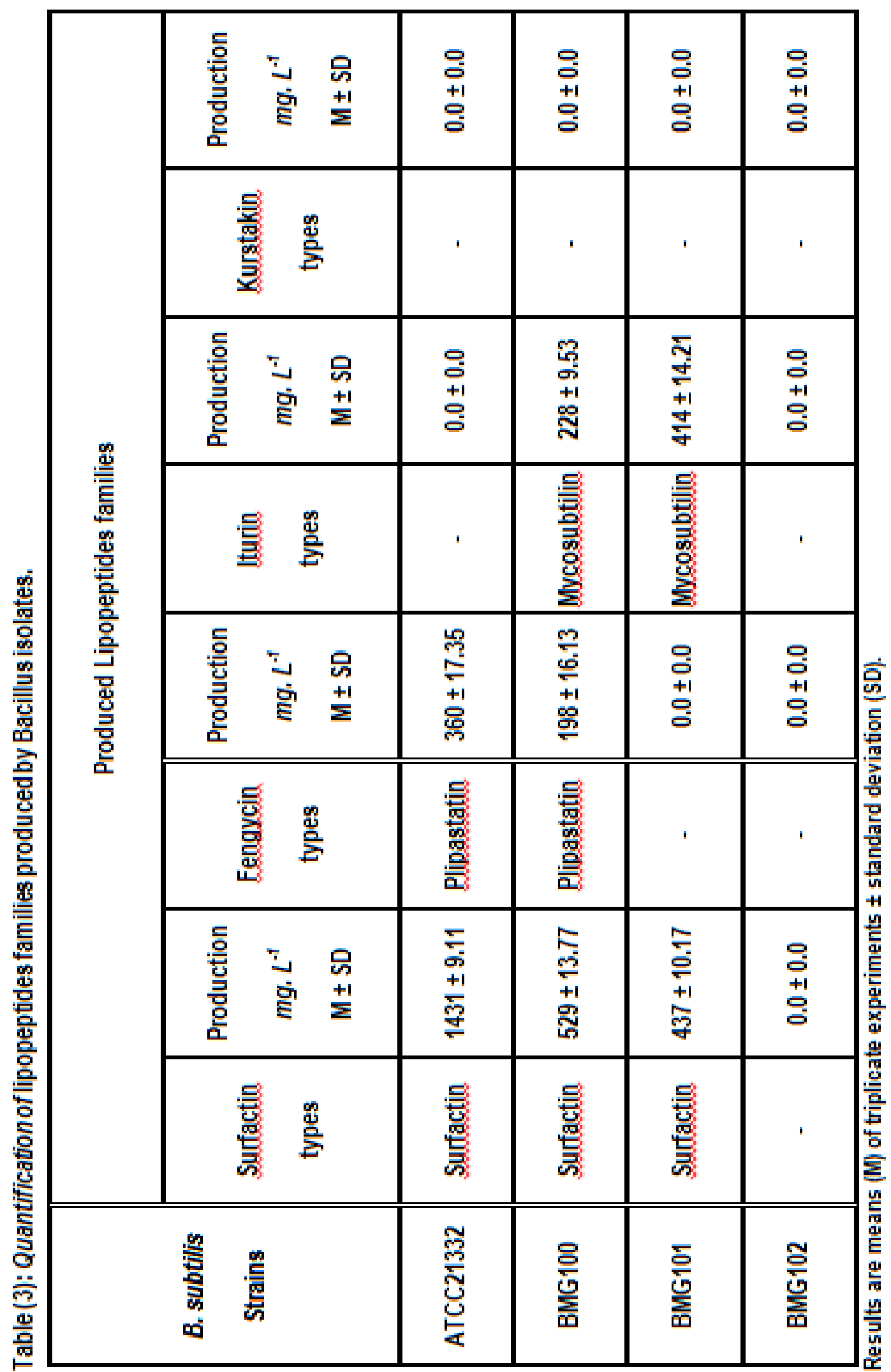




\section{Behavior of $B$. subtilis strains under lipopeptides productivity regimes}

The comparison of the lipopeptides productions obtained by the three oxygen transfer regimes for the $B$. subtilis ATCC21332 and the endophytic Bacillus isolated was studied Regarding lipopeptides production kinetics, surfactin in every case more produced by ATCC21332 than BMG100 and BMG101, and the regime one was the best for total productivity than the other regimes, but the situation is more complex for plipastatin and mycosubtilin production which is slightly higher in regime 2 or 3 , respectively. However at regime 1, ATCC21332 produced surfactin two times more plipastatin or mycosubtilin than BMG100 and BMG101, the surfactin/plipastatin or mycosubtilin ratios are identical for these strains in the different regimes which well illustrated in the Figure (6).

B. subtilis ATCC 21332 showed a big difference in the productivity comparing with the two endophytic strains in the maximum lipopeptides yield observed during the kinetic and production profiles of the three $B$. subtilis strains by the different production regimes. The $B$. subtilis strains showed positive correlation between the microbial growth and increasing of Oxygen Transfer Rate (OTR) in the different regimes. Reduced $\mathrm{pH}$ values were observed with the

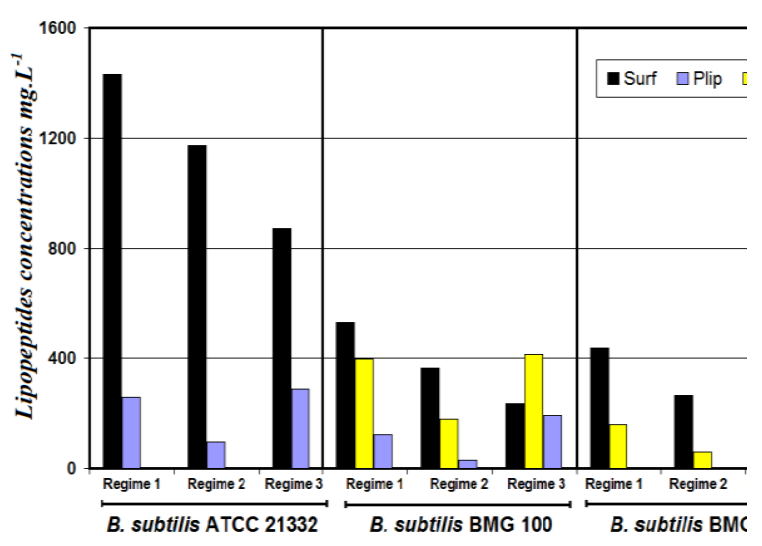

decreasing (OTR) and the $\mathrm{pH}$ values were more reduced for the endophytic strains comparing with the strain ATCC21332, these results confirm that endophytic strains are probably different in a pleitropic regulator production gene which is directly or indirectly involved in lipopeptides regulation biosynthesis (Fahim, 2017).

\section{4. potentials of lipopeptides antimicrobial properties.
4-1. Lipopeptides antibacterial properties

In the present study the effects of primary antibacterial susceptibility testing was performed against three plant pathogenic bacterial strains which were Pseudomonas syringae, Ralstonia solanacearum and Erwinia amylovora. The effect of the three bacterial extracts from the lipopeptides productivity regimes for $B$. subtilis ATCC21332, BMG100 and BMG101 were examined, respectively. The extracted bacterial lipopeptides containing different concentrations of surfactin, plapastitin or/and mycosubtilin mixtures were evaluated as measured inhibition zones. The minimal inhibitory concentrations (MICs) and the Minimum bacterial concentration (MBCs) $\mu \mathrm{g} \cdot \mathrm{mL}^{-1}$ of the net concentrations of lipopeptides were tested and summarized in Table (4). 
Impact of endophytic lipopeptides use against some plant pathogenic

\begin{tabular}{|c|c|c|c|c|c|c|c|c|c|c|}
\hline \multirow{3}{*}{ 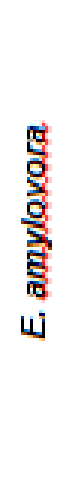 } & 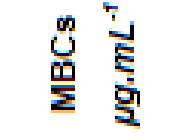 & 을 & 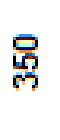 & 只 & న్లి & 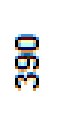 & గ్రి & న్లి & గ్రీ & 只 \\
\hline & 岂 & 品 & స్లి & 导 & 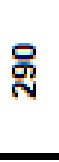 & 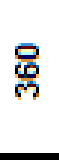 & 品 & ఫ్లి & 品 & ช్ \\
\hline & 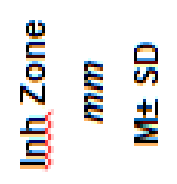 & 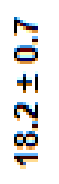 & 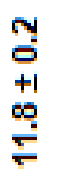 & $\begin{array}{l}\stackrel{0}{0} \\
\stackrel{0}{+1} \\
\stackrel{0}{0} \\
\stackrel{0}{\circ}\end{array}$ & $\begin{array}{l}\stackrel{\infty}{0} \\
+1 \\
\infty \\
\stackrel{0}{\circ}\end{array}$ & $\begin{array}{l}0 \\
0 \\
+1 \\
0 \\
0 \\
\infty\end{array}$ & $\begin{array}{l}\circ \\
\stackrel{0}{0} \\
+1 \\
0 \\
0\end{array}$ & $\begin{array}{l}\stackrel{\infty}{0} \\
+1 \\
\stackrel{+1}{c} \\
\stackrel{m}{\rightleftarrows}\end{array}$ & $\begin{array}{l}\circ \\
\stackrel{0}{0} \\
+1 \\
0 \\
0\end{array}$ & $\begin{array}{l}\stackrel{0}{0} \\
\text { +1 } \\
\stackrel{0}{0}\end{array}$ \\
\hline \multirow{3}{*}{ 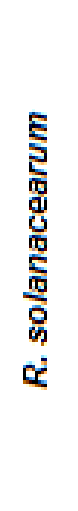 } & 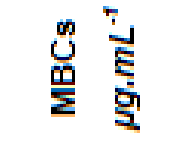 & 을 & 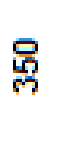 & 只 & న్లి & 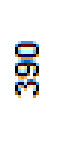 & గ్రి & న్లి & గ్ర్ & $\stackrel{R}{6}$ \\
\hline & 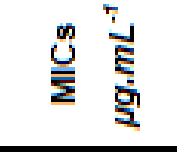 & 品 & న్లి & 亭 & న్సి & 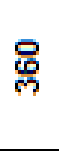 & 品 & ి్లి & 品 & ช్ \\
\hline & 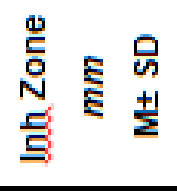 & $\begin{array}{l}+ \\
0 \\
+1 \\
0 \\
0 \\
\infty \\
\infty\end{array}$ & $\begin{array}{l}\stackrel{N}{0} \\
+1 \\
\stackrel{+1}{=} \\
\stackrel{5}{=}\end{array}$ & 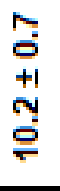 & 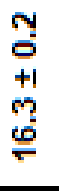 & $\begin{array}{l}\text { ?ִ } \\
+1 \\
+1 \\
0 \\
0\end{array}$ & $\begin{array}{l}\circ \\
\stackrel{0}{0} \\
+1 \\
0 \\
0\end{array}$ & $\begin{array}{c}m \\
0 \\
+1 \\
\stackrel{m}{?}\end{array}$ & $\begin{array}{l}\circ \\
\stackrel{0}{0} \\
+1 \\
0 \\
0\end{array}$ & $\begin{array}{l}\circ \\
\stackrel{0}{0} \\
+1 \\
0 \\
0\end{array}$ \\
\hline \multirow{3}{*}{$\begin{array}{l}\frac{\mathrm{d}}{\mathrm{y}} \\
\frac{5}{5} \\
\frac{5}{5} \\
0\end{array}$} & 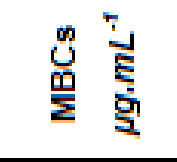 & 을 & 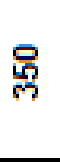 & 只 & స్లి & మ్లి & గ్ర్ & న్లి & గ్ర్ & $\stackrel{R}{6}$ \\
\hline & 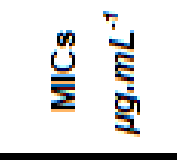 & 品 & న్ & 导 & 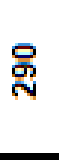 & 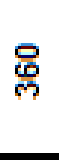 & 品 & ్ా & 品 & ป్ \\
\hline & 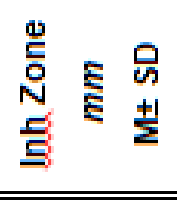 & $\begin{array}{l}\stackrel{0}{0} \\
+1 \\
\stackrel{0}{\circ} \\
\stackrel{0}{\leftarrow}\end{array}$ & $\begin{array}{l}\text { og } \\
0 \\
+1 \\
\stackrel{+}{+}\end{array}$ & $\begin{array}{l}\stackrel{+}{0} \\
0 \\
+1 \\
\infty \\
\stackrel{0}{0} \\
\stackrel{0}{0}\end{array}$ & 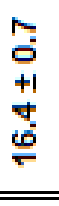 & \begin{tabular}{l}
+ \\
0 \\
+1 \\
\multirow{2}{*}{} \\
$\infty$
\end{tabular} & $\begin{array}{l}\circ \\
\stackrel{0}{0} \\
+1 \\
\circ \\
0\end{array}$ & $\begin{array}{l}\stackrel{\infty}{0} \\
+1 \\
+1 \\
m \\
\dddot{m}\end{array}$ & $\begin{array}{l}\circ \\
\stackrel{0}{0} \\
+1 \\
0 \\
0\end{array}$ & $\begin{array}{l}\circ \\
\stackrel{0}{0} \\
+1 \\
\stackrel{0}{0}\end{array}$ \\
\hline \multirow{2}{*}{ 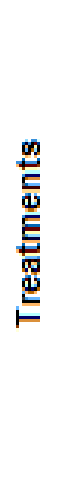 } & 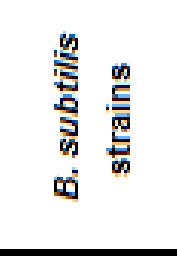 & 弪 & $\frac{\text { 음 }}{\sum_{0}^{0}}$ & $\frac{5}{c}$ & 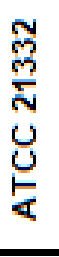 & 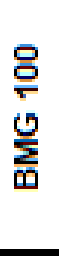 & $\frac{5}{c}$ & 弪 & $\frac{\text { 음 }}{\sum_{0}^{0}}$ & $\frac{5}{0}$ \\
\hline & 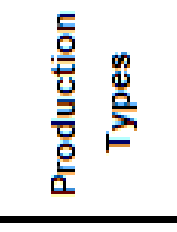 & & 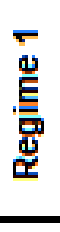 & & & 岕 & & & 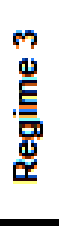 & \\
\hline
\end{tabular}


obtained by the three oxygen transfer regimes

The plates treated with $20 \mu \mathrm{ll}$ of various lipopeptides types notably inhibited all test plant pathogenic bacterial growth, the strong inhibition zone was $19.1 \mathrm{~mm}$ for $P$. syringae by the lipopeptides mixture produced by $B$. subtilis ATCC21332 from regime 1, which also inhibit the growth of $R$. solanacearum and $E$. amylovora strains with inhibition zones of 18.9 and 18.2 $\mathrm{mm}$, respectively. The relatively inhibitory concentrations 280 and 310 $\mu$ g. $\mathrm{mL}^{-1}$ of (MICs) and (MBCs) for all strains. Also, the plates treated with the lipopeptides produced from $B$. subtilis ATCC21332 regime 2 given $16.4,16.3$ and $16.8 \mathrm{~mm}$ with 290 and $320 \mu \mathrm{g} \cdot \mathrm{mL}^{-1}$ of (MICs) and (MBCs). While, the lipopeptides produced from regime 3 given 13.3, 13.1 and $13.7 \mathrm{~mm}$ with 300 and $320 \mu \mathrm{g} \cdot \mathrm{mL}^{-1}$ of (MICs) and (MBCs) for $P$. syringae, $R$. solanacearum and $E$. amylovora, respectively. The lipopeptides produced from $B$. subtilis BMG100 regime 1 given $11.4,11.2$ and $11.8 \mathrm{~mm}$ with 320 and $350 \mu \mathrm{g} \cdot \mathrm{mL}^{-1}$ of (MICs) and (MBCs). Also, the plates treated with the lipopeptides produced from regime 2 given $8.2,8.4$ and $8.9 \mathrm{~mm}$ with 360 and $390 \mu \mathrm{g} \cdot \mathrm{mL}^{-1}$ of (MICs) and (MBCs). While, the lipopeptides produced from regime 3 had no inhibition. effects with 480 and $520 \mu \mathrm{g} \cdot \mathrm{mL}^{-1}$ of (MICs) and (MBCs) for $P$. syringae, $R$. solanacearum and $E$. amylovora, respectively. In addition, the lipopeptides produced from $B$. subtilis BMG101 regime 1 given 10.8, 10.2 and $10.9 \mathrm{~mm}$ with 340 and $370 \mu \mathrm{g} . \mathrm{mL}^{-1}$ of (MICs) and (MBCs). While, those treated with the lipopeptides produced from regimes 2 and 3 had no inhibitions effects with 480 and 520 then 620 and 670 $\mu$ g. $\mathrm{mL}^{-1}$ of (MICs) and (MBCs) of (MICs) and (MBCs) for $P$. syringae, $R$. solanacearum and E. amylovora, respectively.

\section{4-2. Lipopeptides antifungal properties}

The effects of primary antifungal susceptibility testing performed against three plant pathogenic fungal were shown in Aspergillus niger, Phanerochaete chrysosporium and Alternaria alternata, The antifungal effect of the three bacterial extracts from the lipopeptides productivity regimes for $B$. subtilis ATCC21332, BMG100 and BMG101 were examined, respectively. The extracted bacterial lipopeptides containing different concentrations of surfactin, plapastitin or/and mycosubtilin mixtures were evaluated as measured inhibition zones. The minimal inhibitory concentrations (MICs) and the Minimum fungi concentration (MFCs) $\mu \mathrm{g} \cdot \mathrm{mL}^{-1}$ of the net concentrations of lipopeptides were tested and summarized in Table (5)

In the plates treated with $20 \mu \mathrm{l}$ of various lipopeptides types notably inhibited all test plant pathogenic fungi growth, the strong inhibition zone was $21.3 \mathrm{~mm}$ for $A$. niger by the lipopeptides mixture produced by $B$. subtilis BMG100 from regime 3 , which also inhibit the growth of $R$. solanacearum and $E$. amylovora strains with inhibition zones of 20.4 and $20.8 \mathrm{~mm}$, respectively. The relatively inhibitory concentrations 260 and $300 \mu \mathrm{g} \cdot \mathrm{mL}^{-1}$ of (MICs) and (MFCs) for all strains. Also, plates treated with the lipopeptides produced from $B$. subtilis BMG100 regime 1 given 18.1, 17.3 and $17.1 \mathrm{~mm}$ with 300 and $320 \mu \mathrm{g} \cdot \mathrm{mL}^{-1}$ of (MICs) and (MFCs). While, the lipopeptides produced from regime 2 given 19.6, 19.1 and $19.2 \mathrm{~mm}$ with 280 and $310 \mu \mathrm{g} \cdot \mathrm{mL}^{-1}$ of (MICs) and (MFCs) for $P$. syringae, $R$. solanacearum and $E$. amylovora respectively. The lipopeptides produced from $B$. subtilis ATCC21332 regime 1 given $18.2,18.3$ and $17.9 \mathrm{~mm}$ with 290 and $320 \mu$ g.mL $L^{-1}$ of (MICs) and 


\begin{tabular}{|c|c|c|c|c|c|c|c|c|c|c|}
\hline \multirow{3}{*}{ 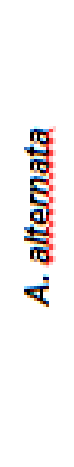 } & $\begin{array}{l}\text { 品 है } \\
\frac{1}{\Sigma}\end{array}$ & న్లి & స్లి & 品 & 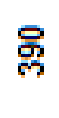 & 응 & జิ & న్లి & ర్లి & 导 \\
\hline & 岕 & న్సి & ి్లి & 卷 & 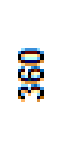 & 品 & 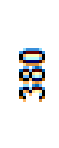 & ర్లి & 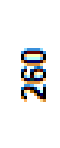 & 응 \\
\hline & 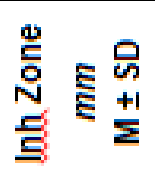 & 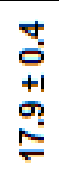 & $\begin{array}{l}\infty \\
0 \\
+1 \\
+1 \\
\stackrel{0}{\circ}\end{array}$ & 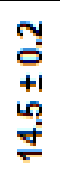 & 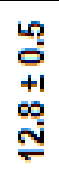 & $\begin{array}{l}\stackrel{\infty}{0} \\
+1 \\
\stackrel{+}{\sigma} \\
\stackrel{\sigma}{\rightleftharpoons}\end{array}$ & $\begin{array}{l}\tilde{O} \\
+1 \\
+1 \\
\infty \\
\stackrel{+}{=}\end{array}$ & $\begin{array}{l}\text { ?o } \\
+1 \\
+1 \\
? \\
?\end{array}$ & $\begin{array}{l}+ \\
0 \\
+1 \\
\infty \\
0 \\
0\end{array}$ & 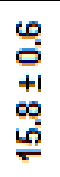 \\
\hline \multirow{3}{*}{ 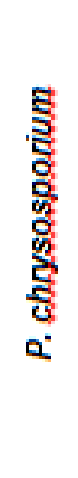 } & 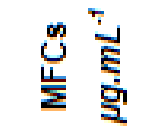 & న్లి & న్లి & 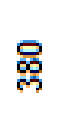 & 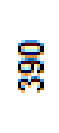 & 응 & శ్ & న్లి & ి్లి & 卷 \\
\hline & 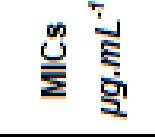 & న్సి & 요 & 尽 & 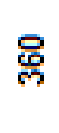 & 品 & 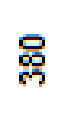 & ర్లి & 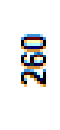 & 응 \\
\hline & 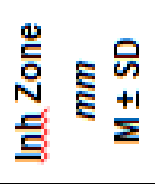 & $\begin{array}{l}\infty \\
0 \\
+1 \\
m \\
\infty \\
\infty\end{array}$ & $\begin{array}{l}m \\
0 \\
+1 \\
m \\
m \\
\stackrel{+1}{=}\end{array}$ & $\begin{array}{l}2 \\
0 \\
+1 \\
0 \\
0 \\
0\end{array}$ & 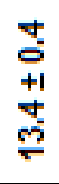 & \begin{tabular}{l}
\multirow{2}{0}{} \\
+1 \\
$\stackrel{+}{-}$
\end{tabular} & $\begin{array}{l}\text { ָ̃ } \\
+1 \\
\stackrel{+}{2}\end{array}$ & 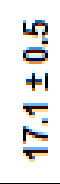 & 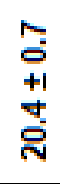 & $\begin{array}{l}\stackrel{\infty}{0} \\
+1 \\
\stackrel{+1}{0}\end{array}$ \\
\hline \multirow{3}{*}{ 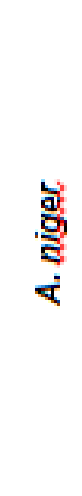 } & 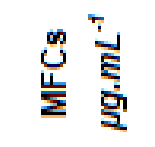 & న్లి & న్లి & 品 & 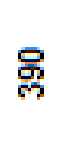 & 응 & ช్ & న్లి & ర్లి & 骨 \\
\hline & 总 हैं & ధ్ని & ర్లి & 昌 & 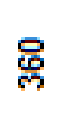 & 品 & 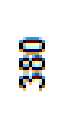 & ర్లి & 只 & 응 \\
\hline & 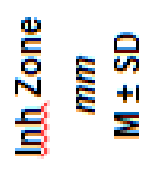 & $\begin{array}{l}\stackrel{+}{0} \\
+1 \\
\stackrel{+1}{\infty} \\
\stackrel{\infty}{-}\end{array}$ & \begin{tabular}{l}
\multirow{0}{0}{} \\
+1 \\
$\stackrel{+}{\infty}$
\end{tabular} & $\begin{array}{l}0 \\
0 \\
+1 \\
+1 \\
0 \\
+2\end{array}$ & 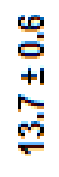 & $\begin{array}{l}m \\
0 \\
+1 \\
0 \\
\stackrel{+}{\sigma}\end{array}$ & 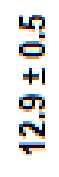 & \begin{tabular}{l}
\multirow{0}{0}{} \\
+1 \\
0 \\
$\stackrel{+}{\sigma}$
\end{tabular} & $\begin{array}{l}\text { ?ִ } \\
+1 \\
+1 \\
? \\
?\end{array}$ & $\begin{array}{l}\mathscr{0} \\
0 \\
+1 \\
0 \\
0 \\
0\end{array}$ \\
\hline \multirow[t]{2}{*}{ 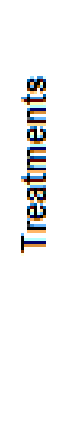 } & 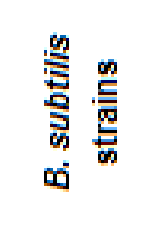 & 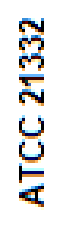 & 응 & $\frac{5}{\sum_{0}^{\circ}}$ & 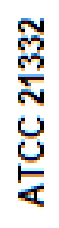 & 음 & 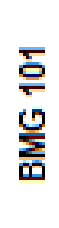 & 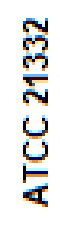 & $\frac{\text { 음 }}{\sum_{0}^{0}}$ & 흠 \\
\hline & 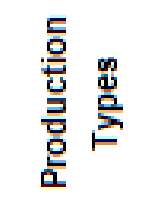 & \multicolumn{3}{|c|}{ 离 } & \multicolumn{3}{|c|}{ 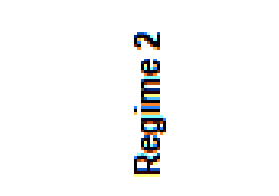 } & \multicolumn{3}{|c|}{ 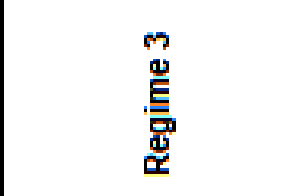 } \\
\hline
\end{tabular}

(MFCs). Also, plates treated with the lipopeptides produced from regime 2 given 13.7, 13.4 and $12.8 \mathrm{~mm}$ with 360 and $390 \mu \mathrm{g} \cdot \mathrm{mL}^{-1}$ of (MICs) and (MFCs). While, the lipopeptides produced from regime 3 given $17.6,17.1$ and $17.4 \mathrm{~mm}$ 
with 320 and $360 \mu \mathrm{g} \cdot \mathrm{mL}^{-1}$ of (MICs) and (MFCs) for $P$.

syringae, $R$. solanacearum and $E$. amylovora, respectively. In addition, the lipopeptides produced from $B$. subtilis BMG101 regime 1 given 14.5, 14.6 and $14.5 \mathrm{~mm}$ with 340 and $380 \mu \mathrm{g} \cdot \mathrm{mL}^{-1}$ of (MICs) and (MFCs). The plates treated with the lipopeptides produced from regime 2 given 12.9, 12.2 and $11.8 \mathrm{~mm}$ with 380 and $420 \mu \mathrm{g} \cdot \mathrm{mL}^{-1}$ of (MICs) and (MFCs). While, the lipopeptides produced from regime 3 given $16.3,16.1$ and 15.8 $\mathrm{mm}$ with 310 and $340 \mu \mathrm{g} \cdot \mathrm{mL}^{-1}$ of (MICs) and (MFCs) for $P$. syringae, $R$. solanacearum and $E$. amylovora, respectively. A positive correlation between the maximum lipopeptides production levels and maximum inhibition zone were found. In this regard, Fahim., (2017) confirmed the bactericidal and bacteriostatic of surfactin especially against various bacterial strains and multidrug resistant bacteria. Moreover fungicidal of mycosubtilin and plipastatin against various fungal strains. Also, the efficiency of surfactin is moderated by comparison of antibiotics especially in low concentration but without chance to produce drug resistant strain of this lipopeptides type (Ongena and Jacques, 2008). Consequently, the occurrence potential of lipopeptides types drug resistant strains is very low due to its specific natural composition that might function as a barrier to bioactive compounds that are reason for antibacterial activity (Jacques, 2008; Fahim., 2017).

\section{Acknowledgements}

This study was conducted by Agricultural Microbiology and Biotechnology Laboratory, Botany Department, Faculty of Agriculture, Menoufia University, Egypt.

\section{REFERENCES}

Abderrahmani, A., A. Tapi, F. Nateche, M. Chollet, V. Leclère, B. Wathelet, $H$. Hacene and P. Jacques (2011). Bioinformatics and molecular approaches to detect NRPS genes involved in the biosynthesis of kurstakin from Bacillus thuringiensis, Appl. Microbiol. Biotechnol., 10.1007/s00253-011-3453-6.

Almoneafy, A.A., G.L. Xie, W.X. Tian, L.H. Xu, G.Q. Zhang and M. Ibrahim (2012). Characterization and evaluation of Bacillus isolates for their potential plant growth and biocontrol activities against tomato bacterial wilt. Afr $\mathbf{J}$ Biotechnol, (11): 7193-7201.

Araújo, W.L., J. Marcon, W. Maccheroni, JD van Elsas, JWL van Vuurde and JL Azevedo (2002). Diversity of endophytic bacterial populations and their interaction with Xylella fastidiosa in citrus plants. Appl Environ Microbiol, (68): 4906-4914.

Bakker, PAHM, CMJ Pierterse and LC. Van Loon (2007). Induced systemic resistance by fluorescent Pseudomonas spp. Phytopathol, (97): 239-243.

Bargabus, R.L., N.K. Zidack, J.E. Sherwood and B.J. Jacobsen (2002). Charac-terization of systemic resistance in sugar beet elicited by a non pathogenic, phyllosphere colonizing Bacillus mycoides, biological control agent. Physiol Mol Plant Pathol, (61): 289-298.

Cockerill, F. R. (2012). Methods for Dilution Antimicrobial Susceptibility Tests for Bacteria that Grow Aerobically; Approved StandardNinth edition (Clinical and Laboratory Standards Institute, Wayne, PA, Clin Microbiol. 50(6): 2034-9.

Chtioui, O., K. Dimitrov, F. Gancel and Nikov (2010). IBiosurfactants production in biofilm reactor and their recovery by pertraction, Process Biochemistry, 45: 1795-1799. 
Coombs, J.T., P.P. Michelsen and CMM. Franco (2004). Evaluation of endophytic actinobacteria as antagonists of Gaeumannomyces graminis var. tritici in wheat. Biol Control, (29): 359-366.

Coutte, F., D. Lecouturier, Ait S. Yahia, V. Leclère, $M$. Béchet, $P$. Jacques and $P$. Dhulster (2010). Production of surfactin and fengycin by Bacillus subtilis in a bubbleless membrane bioreactor. Appl. Microbiol. Biotechnol., 87: 499-507.

Fahim, S., K. Dimitrov, F. Gancel, P. Vauchel, P. Jacques and I. Nikov (2012). Impact of energy supply and oxygen transfer on selective lipopeptide production by Bacillus subtilis BBG21. Biores. technol.; 126: 1- 6.

Fahim, S. and W. Hussein (2016). Antibacterial Potentials of Surfactins Against Multidrug Resistant Bacteria., Research Journal of Pharmaceutical, Biological and Chemical Sciences. 8(3): 10

Fahim, S. (2017). Production Cursors of Lipopeptides Families by Some Bacillus spp., International Journal of Chem Tech Research.; 10 (6): 10961083.

Glare, T., J. Caradus, W. Gelernter, T. Jackson, N. Keyhani, J. Köhl, P. Marrone, L. Morin and A. Stewart (2012). Have Biopesticides Come of Age? Trends in Biotechnology, 30(5): 250-8.

Gancel, F., L. Montastruc, T. Liu, L. Zhao and I. Nikov (2009). Lipopeptide overproduction by cell immobilization on iron-enriched light polymer particles. Process Biochem., 44: 975978.

Holzmann, A. (2010). Latest Development in the Registration of SPP Chemicals in Germany and Europe. Julius-KühnArchiv, 42:89.

Hu, Q.P., J.G. Xu, H.L. Liu, W.L. Chen and Z.Y. Zhu (2006). Isolation and identification of endogenetic bacteria in tomato stems and screening of antagonistic bacteria to Pseudomonas solanacearum. Acta Botanica BorealiOccidentalia Sinica, (26): 2039-2043.

Hussein, W. and S. Fahim (2016). Expression of Ppps and Pfen promoters in Bacillus subtilis under optimal production condition. Res $\mathbf{J}$ Pharma Biolog Chem Sci, 7(2): 11141121.

Hussein, W. and S. Fahim (2017). Detection of synthetases genes involved in non ribosomal lipopeptides (NRLPs) biosynthesis from Bacillus species by bioinformatics and PCR degenerated primers and estimation of their production. Int J Pharma Bio Sci, 8(2): 116-125.

Jackson, T.A.A. (2007). Novel bacterium for control of grass grub. Biological Control: A Global Perspective. 160168, CABI

Jacques, P. (2008). Surfactin and other lipopeptides from Bacillus spp., 57-91. In Soberón - Chávez, G. (ed.), Biosurfactants, Microbiology Monographs. 20, Springer-Verlag Berlin Heidelberg.

Kang, S.H., H.S. Cho, H. Cheong, C.M. Ryu, J.F. Kim and S.H. Park. (2007). Two bacterial endophytes eliciting boot plant growth promotion and plant defence on pepper (Capsicum annuum L.). J Microbiol Biotechnol, (17): 96-103.

Kloepper, J.W., C.M. Ryu and S. Zhang (2004). Induced systemic resistance and promotion of plant growth by Bacillus spp. Phytopathol, (94):12591266.

Landy, M., G.H. Warren, S.B. Rosenman, and L.G. Colio (1948). Bacillomycin an antibiotic from Bacillus subtilis active against pathogenic fungi. Proc. Soc. Exp. Biol. Med., 67: 530-541.

Li, QQ, K Luo, W Lin, HW Peng and XM Luo (2003). Isolation of tomato 
endophytic antagonists against Ralstonia solanacearum. Acta Phytopathol Sinica, (33): 364-367.

Lodewyckx, C., J. Vangronsfeld, R. Porteous, ERB Moore, S. Taghavi, M. Mergeay and D. van der Lelie (2002). Endophytic bacteria and their potential applications. Crit Rev Plant Sci, (21): 583-606.

Marrone, P. (2002). An Effective Biofungicide with Novel Modes of Action. Pesticide Outlook., 193-194.

Maurice, E.S., M. Travor, M.H. Dorothy and W.B. Charles (2009). Isolation and characterization of Leu7-surfactin from the endophytic bacterium Bacillus mojavensis RRC 101, a biocontrol agent for Fusarium verticillioides. J Agric Food Chem, (57): 4287-4292.

Mishra, R.P., R.K. Singh, H.K. Jaiswal, V. Kumar and S. Maurya (2006). Rhizobium mediated induction of phenolics and plant growth promotion in rice (Oryza sativa L.). Curr Microbiol, (52): 383-389.

Needleman, S.B. and C.D. Wunsch (1970). A general method applicable to the search for similarities in the amino acid sequence of two proteins. J. Mol. Biol., 48: 443453.

Nissen-Meyer, J. and IF. Nes (1997). Ribosomally synthesized antimicrobial peptides: their function, structure, biogenesis, and mechanism of action. Arch Microbiol, (167) :67-77.

Nitschke, M. and S.G.V.A.O Costa (2007). Biosurfactants in Food Industry. Trends in Food Science \& Technology, . 18(5):252-9.

Ongena, M. and P. Jacques (2008). Bacillus lipopeptides: versatile weapons for plant disease biocontrol. Trends Microbiol., 16: 115-125.

Ongena, M., P. Jacques, Y. Toure, J. Destain, A. Jabrane and $P$. Thonart (2004). Role of lipopeptides produced by Bacillus subtilis $\mathrm{GA1}$ in the reduction of grey mould disease caused by Botrytis cinerea on apple. $\mathbf{J}$ Appl Microbiol, 96(5): 1151-1160.

Pant, I. M., A. Franzetti, I. Gandolfi, G. Bestetti, M.G. Martinotti, L. Fracchia, T.J. Smyth and R. Marchant (2015). Microbial biosurfactants production, applications and future potential', Applied Microbiology and Biotechnology, 87(2), pp. 427-444. doi: 10.1007/s00253-010-2589-0

Phae, G.P., S. Shoda and K. Kubota (1990). Suppressive effect of Bacillus subtilis and its products on phytopathogenic microorganisms. J. Ferment Bioeng, (69): 1-7.

Pimentel, D. (2005). Environmental and Economic Costs of the Application of Pesticides Pimarily in the United States. Environmental, Development and Sustainability, 7:229-52

Reiter, B., U. Pfeifer, H. Schwab and A. Sessitsch (2002). Response of endophytic bacterial communities in potato plants to infection with Erwinia carotovora subsp. atroseptica. Appl Environ Microbiol, (68): 2261-2268.

Robert, P., K.G. Ryan, F. Ashley, J.R. David and N.D. David (2007). Bacterial endophytes: recent developments and applications. FEMS Microbiol Lett; (278): 1- 9.

Scott, B. (2001). Epichloe endophytes: fungal symbionts of grasses. Curr Opin Microbiol, (4): 393-398.

Senthilkumar, M., V. Govindasamy and K. Annapurna (2007). Role of antibiosis in suppression of charcoal rot disease by soybean endophyte Paenibacillus sp. HKA 15. Curr Microbiol, (55): 2529.

Sturz, A.V., B.R. Christie and J. Nowak (2000). Bacterial endophytes: potential role in developing sustainable system of crop production. Crit Rev Plant Sci, (19): 1-30.

Sturz, A.V. and J. Kinpinski (2004). Endoroot bacteria derived from marigolds (Tagetes species) can decrease soil population densities of 
root-lesion nematodes in the potato root zone. Plant Soil, (262): 241-249.

Sullivan, T.J., J. Rodstrom, J. Vandop, J. Librizzi, C. Graham, C.L. Schardl and TL. Bultman (2007). Symbiont mediated change in Lolium arundinaceum inducible defenses: evidence from changes in gene expression and leaf composition. New Phytologist, (176): 673-679.

Switzer, R. C. and J. M. Hill (1979). Globus pallidus component in the olfactory tubercle: Evidence based on iron distribution. Sot. Neurosci. Abstr. 5: 79.

Tapi, A., Chollet, Imbert, M., Scherens, B. and P. Jacques (2006). New approach for the detection of nonribosomal peptide synthetase genes in Bacillus strains by polymerase chain reaction. Appl Microbiol Biotechnol. 85, 15211531.

Tapi, A., M.C. Imbert, B. Scherens and P. Jacques (2010). New Approach for the Detection of Non-ribosomal Peptide Synthetase Genes in Bacillus Strains by Polymerase Chain Reaction. Appl Microbiol Biotechnol, (85): 1521-1531
Teng, Q.H., H. Cao, Z.L. Cui, Y. Wang, B. Sun, H.T. Hao and Li SP. (2006). PCRRFLP analysis of bacterial 16S rDNA from a typical garden soil in Taihu region. Biodiversity Science, (14): 345351.

Wen, C.Y., Z.G. Yin, K.X. Wang, J.G. Chen and SS. Shen (2011). Purification and Structural Analysis of Surfactin Produced by Endophytic Bacillus subtilis EBS05 and its Antagonistic Activity Against Rhizoctonia cerealis . Plant Pathol J, 27(4): 342-348.

Yanez-Mendizabal, V., H. Zeriouh, I. Vinas, R. Torres, J. Usall, A. de Vicente, A. Perez-Garcia and N. Teixido (2012). Biological control of peach brown rot (Monilinia spp.) by Bacillus subtilis CPA-8 is based on production of fengycin-like lipopeptides. Eur J Plant Pathol. 132: 609-619.

Zhao, K., CG Xiao and DY. Kong (2006). Controlling effect of endophytic bacteria on Ralstionia solannacearum and its antifungal spectrum. $J$ Southwest Agric Univ Natural Science, (28): 314-318. 
تأثير استخدام الليبوييتيدات بكتريا الاندوفيت ضد الميكرويات الممرضة للنبات

أحمد محمود محمد مندور (')، سامح فهيم فرج الله شديد(؟)، ولاء حسين(")،

وفاء حنفي محمود (ץ)، عادل السيد البلتاجي (ץ)

$$
\text { (1) (1) مستثفي شبين القتاطر - القليوبية وفية }
$$

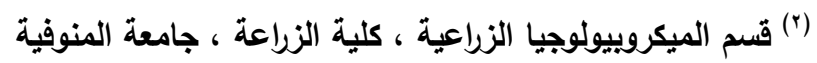

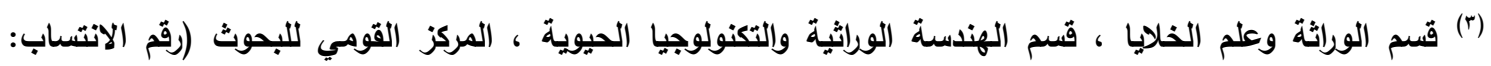

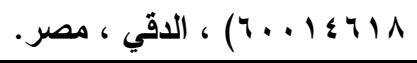

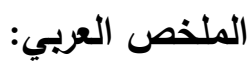

تم عزل اثني عشر عزلة بكتيرية متباينة مرتبطة بالنبات من سيقان خمسة شتلات طماطم مختلفة، كما فصص وجود

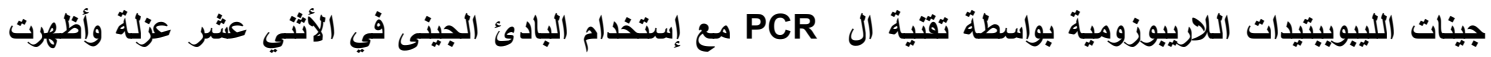

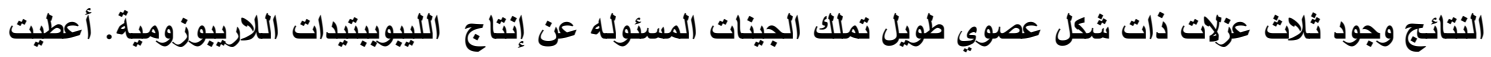

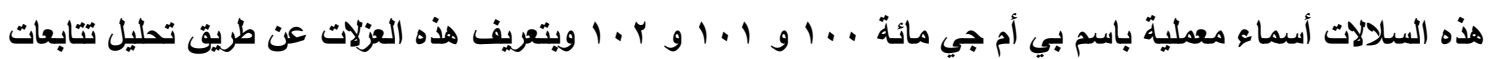

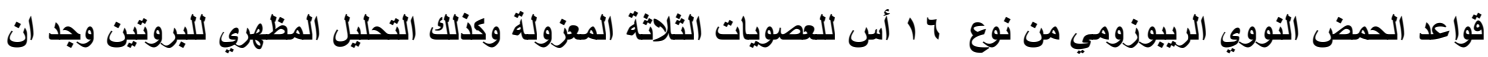

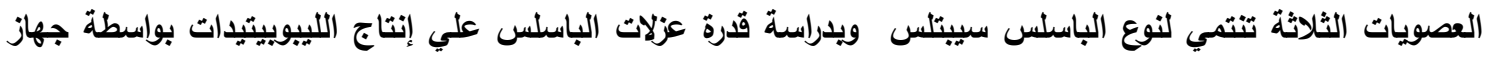

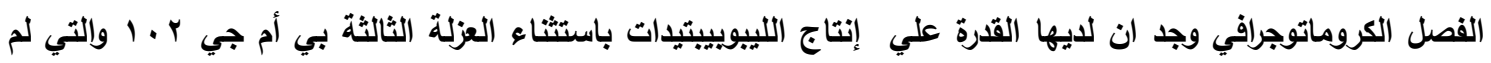
تظهر أي إنتاج. وقد تم دراسة تأثير إستخدام مستويات مختلفة من انتقال الأوكسجين الحجمي علي نوع وكمية الليبوبيتيد

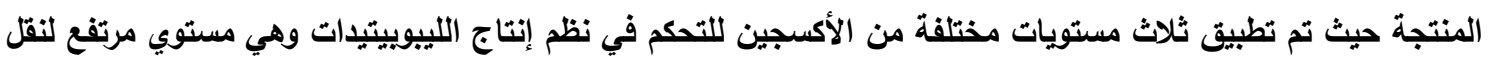

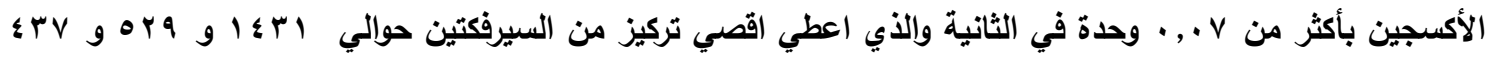

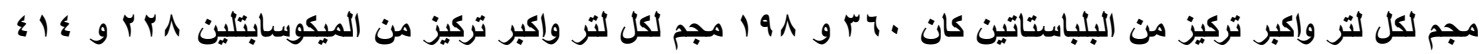

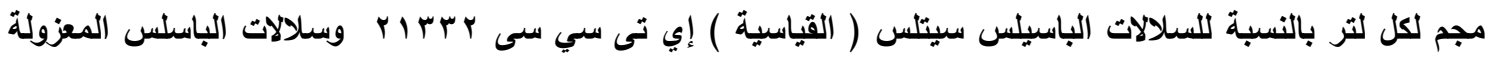

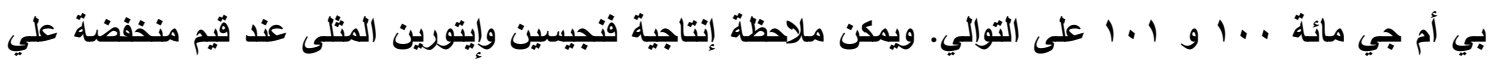

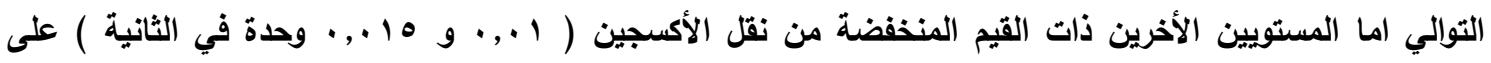

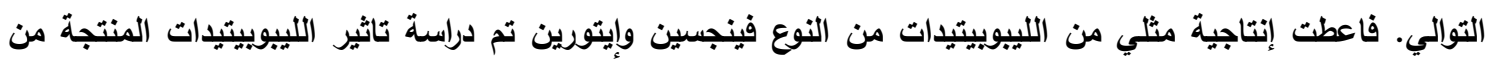

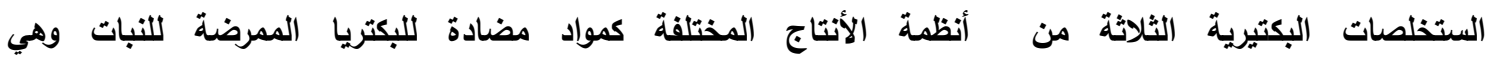
Ralstonia solanacearum - Erwinia amylovora - Pseudomonas syringae Alternaria - Phanerochaete chrysosporium -Aspergillus niger للفطريات الممرضة التالية alternata

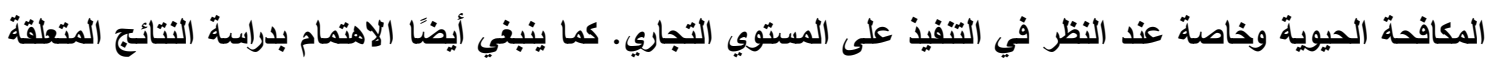
بطرق ونوعية الإنتاج حيث سوف تؤثر ذلك على فعالية الليبوبيتيدات ضد الكائنات الكئية الحية الممرضة المستهدفة. 
Impact of endophytic lipopeptides use against some plant pathogenic

أ.دد/ هناء أحمد أبوقورة مركز البحوث الزراعية - الجيزة

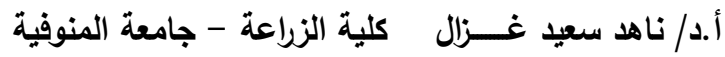


A. Mandour, et al., 
Impact of endophytic lipopeptides use against some plant pathogenic .............. 